\title{
Influence of the Congo's Leaders on its Education
}

\section{Jeremy Cheng}

\author{
jeremyc1501@icloud.com
}

\begin{abstract}
The Democratic Republic of Congo (DRC) is challenged by constant political violence, economic instability, and a variety ofhumanitarian crises. This can be attributed in part to the educational system in the country, which has been adversely affectednot only by colonial influence but by ongoing corruption and turbulent political change as well. As the parties controlling the DRC changed, so too did the nation's educational system. Prior to being overtakenby King Leopold II in 1884-85 and then Belgium in 1908, King Afonso I provided his Kongo kingdom with a beneficial education system. The education system implemented by Leopoldsought toreinforce his own economic interests rather than educate the people under his rule. Belgian colonial rule was slow to improve the state of education in the region.In 1960, the Congo's first native leader, Patrice Lumumba, achieved independence for the nation. Lumumba's proposals left behind an educational legacy that flourished shortly after his death;however, the systemwas not maintained by subsequent puppet leaders such as MobutuSeseSeko and Laurent-DésiréKabila. Ultimately, the Congo's plagued educational system is not only invariably linked to its ever-changing political and economic states, but also to the historical impressions left by its leaders throughout history.
\end{abstract}

\section{INTRODUCTION}

According to the Borgen Project, the Democratic Republic of the Congo "is one of the richest countries in the world in terms of natural resources." ${ }^{1}$ The country has an abundance of natural resources, which include natural gas, precious metals, and land, adding up to an estimated twenty-four trillion dollars. In spite of this natural wealth, citizens today make around eight hundred dollars a year and $63 \%$ of the population lives under the poverty line. Compounding this problem, the Congo sustains a substantial amount of national debt and is in grave need of foreign aid. ${ }^{2}$ This deficit can be attributed to a number of problems-including the historical impact of a sustained lack of investment in education by colonial leaders. Before the advent of colonial Belgian rule, the Congo was controlled by a number of influential leaders, such as King Afonso I, who valued the importance of education. ${ }^{3}$ Leopold's arrival marked an era in which he used education of the Congolese as labor to extend his own power and interest. Congolese education improved in the mid-20th century under Prime Minister Patrice Lumumba. However,subsequent leaders under Western control-such as Joseph Mobutu—failed to maintain the improved education system. While some leaders of the Congo made positive changes to enhancing the education system of the nation, closer consideration of the enduringnegative impacts of Leopold and colonial leadership allows for a more nuanced understanding of the current economic state of the Congo. It will become clear, after consideration of the history of national education systems in the Congo, that the region has thusfar been incapable of escaping its Colonial past.

1. Connor Keowen, "Rich in Resources but Why is the Democratic Republic of Congo Poor?" The BorgenProjecti Blog, August 1, 2017, https://borgenproject.org/why-is-the-democratic-republic-of-congo-poor/.

2. Ibid.

3. Steve Johnson, "King Leopold II's Exploitation of the Congo from 1885 to 1908 and its Consequences" (B.A. thesis, University of Central Florida, 2014), 21. 


\section{Regime Change and Educational Policy}

Before Europeans were able to control the Congo, the region was divided into local, self-governing kingdoms. These kingdoms acquired technological advances through economic relationships with countries like Portugal, which allowed indigenous Africansto exchange natural resources for guns and manufactured goods. ${ }^{4}$ These economic relationships allowed local kings to improve upon already existing social and political structures such as public education. The Kingdom of Kongo was particularly noteworthy in this regard, where AfonsoI was motivated by his vision to modernize society by investing in learning. Through his mutually beneficial relationships with Kings Manuel I and João III of Portugal, Afonso was able to extend and improve the quality of education he offered his people. These relationships yielded a number of important insights and benefits, as the Portuguese advised Afonso on how he should managehis kingdom.Afonso's relationship with the Portuguese included state visits, where he traveled to Portugalto observe European pedagogical models. ${ }^{5}$ As E. Jefferson Murphy states:

Schools for the nobility were established in Kongo itself. As befitted a king who was proud, and who regarded himself (and was accepted) as a peer of the Portuguese monarch, he paid for these educational services by sending slaves, copper, and iron to Portugal. Afonso intended to make of Kongo-a Christian nation, equipped fully with Western knowledge and technology and capable of playing a dignified role in the world, as well as in Africa. ${ }^{6}$

In addition to forming an advantageous relationship with Portugal, Afonso I also made other attempts to improve education, such as hiring school teachers and instructors for various trades-including masons and strategists. While masonscould teach others to improve the infrastructure of the kingdom, strategists could teach martial tactics. ${ }^{7}$ His leadership created opportunities for the Congolese to pursuehigher education, which contributed to the overall improvement of the nation's economy. However, Afonso's legacy-including subsequent efforts made by other Congolese kingdoms-in education, in infrastructure, and the economy would soon fall apart after the Belgian King Leopold II gained control of the region. ${ }^{8}$

King Leopold II gained control of the Congo through the Conference of Berlin in 1884. This conference was attended by a number of European imperial powers and the purpose was to divide the land of Africa among the European states in an effort to reduce future conflict. At this conference, Leopold made a number of beneficent claims, including suggesting thathe wanted to set up a colony in the Congo in order to abolish the ongoing slave trade. He assured the leaders at the Berlin Conference that his influence in the Congo would also serve to civilize and enlighten the native people through Christianity and European education. His seemingly humanitarian policies and philanthropic reasons for colonizing the Congo were accepted by leaders at the Conference; thus, they granted Leopold control of the region. Leopold further convinced several countries to raise funds for Leopold's company, the International African Association (IAA) - an organization that created to fund travel for missionaries in the Congo. ${ }^{9}$ The IAA, however, was eventually dissolved; Leopold confiscated the funds to enhance his power and amplify his exploitation of both human and natural resources. Although Leopold

4. E. Jefferson Murphy, History of African Civilization(New York: Crowell, 1972).

5. Martin Ewans, European Atrocity, African Catastrophe: Leopold 2, the CongoFree State and Its Aftermath (London: Routledge, 2002).

6. Murphy, History of African Civilization, 193.

7. Jan Vansina, Kingdoms of the Savanna(Madison: University of Wisconsin Press, 1966), 47.

8. Murphy, History of African Civilization.

9. "King Leopold II of Belgium Establishes the Congo Free State," inAfrica, ed. Jennifer Stock (Farmington Hills, MI: Gale, 2014), 213-17. 
presented himself as having good intentions-such as to educate the Congolese-his real motives were to secure personal power and wealth at the expense of the native Congolese people.

Leopold's kingdom, the Congo Free State, destroyed both the economy and the society of the people of the Congo. Rather than advancing the Congolese society through ongoing investment in education, Leopold focused solely on maximizing personalprofit through the collection of raw materials such as rubber and ivory. Global demand made rubber and ivory two of the most valuable raw resources in the 19th century and, as a result, the economies of many colonial societies were almost wholly reliant on the collection of these resources. After the price of ivory plummeted in 1890s, Leopold divertedhis attention to the extractionof rubber-then in high demand due to the invention of inflatable tires for bicycles and automobiles. In an effort to increase rubberoutput, Leopold brutalized Congolese women and children by confining them in hostage-houses. Additionally, he set quotas for rubber harvests and punished those who failed to meet requirements by cutting off the workers' right hands. This period was later called "red rubber," which referred to the blood of the Congolese. In Red Rubber, Edmund Morelquotes a report from Banks of the American Baptist Missionary Union, in 1896, which describes the extent of Leopold's brutality:

Describes raid of State troops upon the villages of BandakaWajiko. Cause, poor quality of rubber. Questions soldiers, and is told fifty people have been killed and twenty-eight taken prisoners. ... Visits the raided village. In a little shed lay one of my late school children, a promising young lad. I lifted the leaves by which he was covered, and saw his right hand cut off. I then went through the village and saw the people burying their dead. ... All the bodies had the right hand cut off. ${ }^{10}$

Furthermore, Adam Hochschild has estimated that an additional ten million native deaths occurred during and in the wake of Leopold's reign. ${ }^{11}$ Due to extensive violence and bloodshed, important componentsof Congolese life and society, such as education, were neglected. Due to the stringent demands of the quota system and the severity of concomitant punishment, the Congolese focused on survival and meeting basic needs rather than the "luxury" of education. ${ }^{12}$

Leopold continued tomanipulate the limited Congoleseeducational opportunities for personal gain, directlycontradicting his proposals at the Berlin Conference. He cutoff contact with nearby colonies and prevented unsponsored missionaries from entering the Congo Free State. This imposed isolation preventedoutsiders from witnessing his ongoing brutality. Furthermore, Leoppold funded Catholic missionaries-a far from neutral influence-who worked under his authority to reinforce his exploitative agricultural system. ${ }^{13}$ Thus, education in the Congo suffered from a lack of breadth of career fields and training programs due to the limitations of Catholic pedagogical models. For example, Leopold only supported education that would producesoldiers, miners, and farmers. On April 27, 1890, the Leopoldwrote:

I believe we must set up three children's colonies. One in the Upper Congo near the equator, specifically military with clergy for religious instruction and for vocational education. One at Leopoldville under clergy with a soldier for military training. One at Boma like that at Leo... The aim of these colonies is above all to furnish us with soldiers. ${ }^{14}$

10. E. D. Morel, Red Rubber: The Story of the Rubber Slave Trade Flourishing on the Congo in the Year of Grace 1906(New York, Haskell House, 1970), 45-46.

11. Adam Hochschild, King Leopold's Ghost: A Story of Greed, Terror, and Heroism inColonial Africa(Boston: Houghton Mifflin, 2005), 233.

12. Morel, Red Rubber.

13. Ewans, European Atrocity, 241.

14. Hochschild, King Leopold's Ghost, 134.

American Research Journal of History and Culture

Page 3 
Influence of the Congo's Leaders on its Education

Additional evidence of the limited career choices is noted by Martin Ewan, who states, "There was also a strong bias in favour of preparing Africans solely to become members of the workforce required by the mining, agricultural and other companies." ${ }^{15}$ Thus, Leopold did not want to provide his subjects with education that would encourage critical thinking abilities. He believed that such abilities would undermine his power and influence. Leopold's educational strategy-limiting the number of careers in the Congo-ultimately resulted in a stunted society that quickly fell behind the educational standards of other nearby colonies. ${ }^{16}$

The full extent of Leopold's actions in the Congo Free State were eventually discovered in 1908 and accounts of the brutal conditions and punishments experienced by the Congolese were exposed to the rest of Europe. Widespread international furor forced the Belgian parliament to rescind the agreement to give the territory to Leopold in 1908. Although the Congo experienced a regime change, the Belgian government also exhibited limited interest developing the country's educational policies in a way that would benefit the Congolese.Like Leopold, instead of directly facilitating education in the Congo, the Belgians transferred this responsibility to Catholic missionaries. ${ }^{17}$ The Belgium government's disinterest in developing educational policies with long term local benefits resulted in a shortage of diversified professional schools and a lack of higher education opportunities. The prevalence of religious schools led to poor curriculum and low quality educators at the primary school level, which eventually led to low enrollment percentage in secondary schools and higher education. In the wake of the considerable economic loss that Belgium suffered during World War I and its lethargic post war economy, the Belgian government had no energy to reflect its policies in the Belgium colony, resulting in systematic financial neglect of educational systems in the Congo for several decades.

The Belgian parliament believed that the Congoleseshould only learn what was useful for them and only focus on "practical" subjects such as agriculture and trading. ${ }^{18}$ Some reports during that time, echoing the Belgian government's sentiments, even suggestedthat the Congolese were not ready for advances in education. ${ }^{19}$ These beliefs and the corresponding educational policies were rather distinct from the colonial educational policies of Britain and France. Both British and French colonies had clear pedagogical goals, factoring native culture into the design of their curriculum. The British, for example, advocated fora culture adaptation principle, emphasizing "the creation of a group of educated Africans, who at the same time would be 'rooted in their own culture."'20 The French applied an assimilationist policy which "aimed at the creation of an elite cherishing metropolitan values-Black Frenchmen." ${ }^{21}$ In order to achieve their goals, both British and French colonies created many opportunities for professional and higher education. In British colonies, university colleges were established in Nigeria-at Ibadan in 1948-and in Egypt-at Makerere in 1949 and Khartoum in 1951. Furthermore, a College of Technology was founded in in Ghana at Kumasiin 1951 and the Royal Technical College of East Africa was founded in Nairobi in 1954. In French colonies of the same period, the federal schools included two normal schools—one school of medicine and pharmacy—one veterinary school, one school for marine mechanics, and

15. Ewans, European Atrocity, 241.

16. Johannes Fabian, "Missions and the Colonization of African Languages: Developments in the Former Belgian Congo," Canadian Journal of African Studies 17 (1983): 169

17. Jessica Achberger, "Belgian Colonial Education Policy: A Poor Foundation for Stability," http://ultimatehistory project.com/belgian-congo.html.

18. J. S. Harris, "Education in the Belgian Congo,"The Journal of Negro Education, 15.3 (1946): 419.

19. Marie Elizabeth Dunkerley, "Education Policies and the Development of the Colonial State in the Belgian Congo, 1916-1939” (Ph.D. diss., Exeter University, 2009), 40.

20. Remi P. Clingnet and Philip J. Foster, "French and British Colonial Education in Africa," Comparative Education Review8.2 (1964): 191-98.

21. Ibid

American Research Journal of History and Culture

Page 4 
one technical school. ${ }^{22}$ Comparatively, in the Congo, it was only in 1954 that the first Congolese citizen was admitted to a university for purposes other than religious education. ${ }^{23}$

As mentioned above, rather than instituting a well-structured, state-sponsored education program, the Belgian government subsidized missionaries to set up missionary schools. These missionaries, whose main motives were to promote religion and colonial domination, became the primary group responsible for educating Congolese children. ${ }^{24}$ Although these missionaries were knowledgeable about Catholicism, they did not have much experience or knowledge in other subjects, which resulted in their inability to teach Congolese children well. As a result, the Congolese were deprived of a sufficiently broad education such thatonly a small percentage of graduates from primary schools in the Congo were admitted to secondary schools. Barbara A. Yates has studiedthe structural imbalance between levels of this educational system. She states, "While 98 percent of the school enrollment was in primary schools, somewhat less than 2 percent of the enrollment was in secondary schools and a tiny fraction of one percent was in higher education."25

The lack of secondary school education for the Congolese not only prevented them from having the opportunities to seek higher education or profession training, but also created a seemingly insurmountable lack of educated and trained Congolese. With a limited number of secondary school students, there was always a shortage of qualified educators and local leaders who could pursue measures to reform the stagnant, local educational system and thereby improve structural imbalances between levels of the education systems. For example, the Educational Secretary of the Congo Protestant Council in 1945 stated: "a very large number of village schools are still below the lowest recognized standard. Many teachers have had hardly any formal training." ${ }^{26}$

The primary educational policy of the Belgian government was not aimed at contextualizing education to the languages and needs of the Congolese people. Although the design of this system was dominant during Belgian control from 1908-1960, divergent views that supported a more sociocultural approach to education could be found in the history of the Congo. For example, in the early 1920s, a more progressive view was held by Louis Franck, the first Minister of the Colonies. He was the first person at the government level to see a need to invest in "the Congo" instead of simply extracting resources from it. Franck was a strong supporter of Catholic education within indigenous Africa. Franck's perspective on colonial education is best described in his own words:

When concerned with the moral education of the natives, it is important to ensure that we do not transfer our European conceptions to Africa. ... If Europe has perhaps passed the age of religions, Africa is certainly in the age of religions. No factor exists that may act with more energy and more power on the moral education of the natives than the religious action. ... Consequently, we shall protect the evangelisation in Africa, without moreover establishing a distinction between the Christian religions. ${ }^{27}$

22. Encyclopaedia Britannica, s.v., "Education in British colonies and former colonies," https://www.britannica. com/topic/education/Education-in-British-colonies-and-former-colonies\#ref47720.

23. Achberger, "Belgian Colonial Education Policy."

24. Harris, "Education."

25. Barbara A. Yates, "Structural Problems in Education in the Congo (Leopoldville)," Comparative Education Review 7.2 (1963):159. See Appendix A for Yates's data.

26. Harris, "Education," 422.

27. Jan Briffaerts, "When Congo Wants To Go To School-Educational Organisation In The Belgian Congo (1908-1958)," The Rozenberg Quarterly Blog, http://rozenbergquarterly.com/when-congo-wants-to-go-toschool-educational-organisation-in-the-belgian-congo-1908-1958/. 
In 1922, Franck brought a commission of experts together to frame the colonial educational structure. The Franck's Commission's recommendation was the foundation of anew curriculum in 1929:

The education was to be attuned to the environment of the Congolese and was not to start from a European perspective; moral education was much more important than (technical) education; education was to be given in the native language as much as possible; the cooperation with the missions with regard to education was to be given absolute priority. ${ }^{28}$

Despite the commission's stated goalof establishing animproved path toeducation for the Congolese people, it was hindered by the advent of World Wars I and II. The ongoing effect of these wars left little substantial support both for the Belgian government and Frank's commission. However, many of their more progressive views were embraced and implemented in the late 1950s before the Congo's independence.

In addition to advocating for an educational system designed for the needs of the native Congolese, there was an increasing demand for education outside the Catholic network. For example, Jan Briffaertstates that although the work by the missions were greatly appreciated, the Parliamentary Commission for the colonies did not want the monopolization of education by the missions. ${ }^{29}$ As a result, several new curricula were developed between the 1920s and 1950s; further, the demand for officially neutral education for the Congolese began to develop clearly by the end of the 1940s.

A prominent political leader in education during this transitional period was Auguste Buisseret, the Minister of the Colonies of Belgium from 1954-1958. As soon as he took office, he created a network of public, primary, and secondary schools open to all Congolese. In 1956, he founded the University of Lubumbashi. Buisseret's active education policies established a preliminary educational system foundation for the future public education development after the independence of the Congo in $1960 .^{30}$

In June of 1960, Patrice Lumumba helped his country to gain independence from Belgium. He was elected as the first Prime Minister of the DRC. ${ }^{31}$ As a nationalist, Lumumba played a significant role in transforming the DRC from colony to republic. Lumumba did not follow the already established colonial education system in the Congo which had beendominated by missionaries and incompetent teachers. As Leo Zelig suggests, "Lumumba forged his own path. Before long he chose his own schools, made his own decisions and fought his own battles. As an adolescent, he immediately stood out, as a popular and strong character. Friends and family remember him as curious and audacious, confident in his own abilities." ${ }^{32}$ Such characteristics led him to challenge and question the education in the Congo at the time and allowed him to create his own ideas, eventually leading to him developing his own pedagogical philosophy. In a letter he wrote to his friend Emile Luhahi in 1954, Lumumba says:

I have projects which are centred to one ideal: to have a thorough education... because for me wealth has no value. I prefer to have a competent education than to be rich, ignorant...what is my educational experience? It is certainly thanks to my own effort, my perfectionism, my perseverance...today even Europeans characterise me as formidable...the Europeans take me for a man of superior education. ${ }^{33}$

28. Ibid.

29. Ibid.

30. Wikipedia, s.v. “Auguste Buisseret,"https://fr.wikipedia.org/wiki/Auguste_Buisseret.

31. Guy Vanthemsche, "Lumumba, Patrice,"Encyclopedia of Western Colonialism since 1450, ed. Thomas Benjamin, 2 vols. (Detroit, Macmillan Reference USA, 2007), 2:740-41.

32. Leo Zeilig, Lumumba: Africa's Lost Leader(London, Haus, 2008), 19.

33. Ibid, 30.

American Research Journal of History and Culture Page 6 
Lumumba's personal experience with education showed his dedication to improving himself and deeply influenced his desire to improve education systems in the DRC after he became Prime Minister. Heunderstood many of the gifted children in the DRC who had intellectual desires similar to his. He also wanted to end the colonial practices of Belgian education in the DRC by proposing his own education policy. In a live address to the youth of the DRC, Lumumba stated:

Many brilliantly gifted young people turned down the opportunity to receive a higher education for the simple reason that they no longer wished to be indoctrinated by the colonialists, who wanted to turn our young men and women into eternal servants of the colonial regime. ${ }^{34}$

His effortsto reform the education system were further displayedthrough his political party, the Mouvement National Congolais (MNC). Regarding the goals for education in the DRC, Lumumba and other leaders of the MNC stated that: "In matters of education, free development of primary, secondary, technical and superior education. Compulsory schools. Suppression of all measures hindering the student from achieving his choice of philosophy; freedom for parents to choose and education of their choice. ${ }^{35}$ However, Lumumba was assassinated in 1961 due to his radical speeches, which led Belgium and other Western countries to see him as a threat. ${ }^{36}$ Although he did not live long enough to help the DRC transform, his proposals and legacy left a lasting mark on the DRC's educational trajectory. Future prime ministers would beinspired by his example and thus strive forbetter educational opportunities for the Congolese people. Many of the problems inherent ineducation during the Belgian reign were improved in the 1960s, such as curriculum for women and the promotion of secondary education. The most prominent problem was the lack of skilled teachers, as many were not qualified to educate others with only two years of primary education. It was at this point that UNESCO stepped in to train Congolese teachers in addition to recruiting qualified teachers from foreign nations. Teachers, furthermore, began to receive consistent pay. Curriculum improvements-such as shapingchildren's classes around student interests-led tohigher admission rates to Congolese secondary schools. Educationalopportunities for women also increased, as such opportunitieswere previously scarce. Education was a clear national priority in the 1960s.At onepoint, around 38\% of the DRC's annual budget was put towards financing education. ${ }^{37} \mathrm{By} 1970$, the DRC would developone of the best university infrastructures in Africa. ${ }^{38}$

Unfortunately, this golden age of education was not maintained after Joseph Mobutu seized power in 1965. As a puppet leader under the control of Belgium and the United States, Mobutu had no interest in improving the education of the Congolese, thereby bringing an end to any further educational advances that had been inspired by Lumumba and the MNC. The country did experience a short period of intense nationalism under Mobutu's leadership. Thisideological shift led to the nationalization of all schools in the country. However, the movement ultimately failed to transform the Congo. This may be due to the lack of educated individuals who could replace Lumumba as a respected leader. Zeilig states:

Despite the universal popularity of Patrice Lumumba among the people of the Congo in July 1960, his regime and his ideal of a unitary and independent Congo was toppled in less than a year... the people of the Congo wanted Lumumba to live but they lacked the knowledge, the techniques of popular struggle and organisation that might have saved him. ${ }^{39}$

34. James Ching, "Public Education Trends in the Democratic Republic of the Congo: 1960-1967," Comparative Education Review 12.3 (1968): 323.

35. Ibid.

36. Vanthemsche, "Lumumba, Patrice."

37. Ching, "Public Education Trends," 327-37.

38. Encyclopaedia Britannica,s.v., "Education in Belgian colonies."

39. Zeilig, Lumumba, 143.

American Research Journal of History and Culture 
Influence of the Congo's Leaders on its Education

Rebels later ousted Mobutu and the following years of wars drove the country back into turmoil. The seemingly endless chaos and political and financial instability devastated the national education system. As of May 2019, the Global Partnership for Education (SMEs) "estimated that 3.5 million, or $26.7 \%$ of children of primary school age are out of school, [in the DRC]." ${ }^{\prime 0}$

\section{CONCLUSION}

Overall, the history of education in the Congo has been characterized by the leaders who controlled the country. Leaders such as Afonso, Franck, and Lumumba were able to improve the state of education in the Congo while the influence of others such as Leopold and the Belgian government only sought self-enrichment. Since the early 15th century, the state of education in the Congo has been in constant flux: first vivified by Afonso, later perverted by Leopold, neglected by the Belgian government, stimulated by Lumumba, and then disrupted by the recent outbreak of wars. Lumumba's death, in particular, resulted in a hole which no one could fill. By the time the Congo gained independence, there were no Congolese army officers, engineers, agronomists, or physicians. The nation could boast only fewer than 30 university graduates ${ }^{41}$ Without a competent, local leader, and help from intellectuals to shape formal policy, the country was soon turned back into the hands of Belgium and its puppet leader Mobutu. The turmoil in post-Mobutu years further demonstrates that the Congo has never completely emerged from the shadow of its colonialist past and still carries the scars of its ill-functioned education system.

\section{APPENDix A}

Grade Distribution of Pupils in State-Supported Schools in the Congo, 1959-1960

\begin{tabular}{|c|c|c|}
\hline Grade & Pupils & Percentage of Total \\
\hline 1 & 585,632 & 40.0 \\
\hline 2 & 313,696 & 21.3 \\
\hline 3 & 232,237 & 15.8 \\
\hline 4 & 159,595 & 10.7 \\
\hline 5 & 107,840 & 7.2 \\
\hline 6 & 44,337 & 3.0 \\
\hline Sub-total & $1,443,337$ & 98.0 \\
\hline 7 & 11,786 & 0.8 \\
\hline 8 & 7,641 & 0.5 \\
\hline 9 & 5,864 & 0.4 \\
\hline 10 & 3,492 & 0.2 \\
\hline 11 & 708 & 0.1 \\
\hline 12 & 501 & - \\
\hline Sub-total & 29,992 & 2.0 \\
\hline Total & $1,473,329$ & 100.0 \\
\hline
\end{tabular}

Source: Primary; UNESCO Mission to the Congo, Etude 7. Secondary; UNESCO Mission to the Congo, Etude 5. There were an additional 20,000 pupils in state-supported "post-primary" or senior "elementary" schools which were terminal

40. Seehttps://www.globalpartnership.org/country/democratic-republic-congo.

41. Hochschild, Adam. King Leopold's Ghost: A Story of Greed, Terror, and Heroism inColonial Africa. Boston, Houghton Mifflin, 2005, p. 301 


\section{REFERENCES}

Achberger, J. “Belgian Colonial Education Policy: A Poor Foundation for Stability.” http://ultimatehistoryproject. com/belgian-congo.html.

Briffaerts, J. "When Congo Wants to Go to School-Educational Organisationin the Belgian Congo (19081958)." Rozenberg Quarterly: The Magazine. http://rozenbergquarterly.com/when-congo-wants-to-go-toschool-educational-organisation-in-the-belgian-congo-1908-1958/.

Ching, J. "Public Education Trends in the Democratic Republic of the Congo: 1960-1967."Comparative Education Review 12.3 (1968): 323-37.

Clingnet, R. P. and P. J. Foster. "French and British Colonial Education in Africa." Comparative Education Review 8.2 (1964): 191-98.

Dunkerley, M. E. "Education Policies and the Development of the Colonial State in the Belgian Congo, 19161939." Ph.D. diss., Exeter University, 2009.

Ewans, M. European Atrocity, African Catastrophe: Leopold 2, the CongoFree State and Its Aftermath. London: Routledge, 2002.

Fabian, J. "Missions and the Colonization of African Languages: Developments in the Former Belgian Congo." Canadian Journal of African Studies 17 (1983): 165-87.

Harris, J. S. "Education in the Belgian Congo."The Journal of Negro Education 15.3 (1946): 410-26. doi: $10.2307 / 2966110$

Hochschild, A. King Leopold's Ghost: A Story of Greed, Terror, and Heroism inColonial Africa. Boston: Houghton Mifflin, 2005.

Johnson, S. "King Leopold II's Exploitation of the Congo from 1885 to 1908 and its Consequences." B.A. thesis, University of Central Florida, 2014.

Keowen, C. "Rich in Resources but Why is the Democratic Republic of Congo Poor?"The Borgen Project Blog. August 1, 2017, https://borgenproject.org/why-is-the-democratic-republic-of-congo-poor/.

Lumumba, P. “Address to Congolese Youth, August 1960." Pp. 33-36 in Fighter for Africa's Freedom. Transcribed by Thomas Schmidt. Moscow: Progress Publishers, 1961.Available online: https://www.marxists.org/ subject/africa/lumumba/1960/08/youth.htm.

Morel, E. D. Red Rubber: The Story of the Rubber Slave Trade Flourishing on the Congo in the Year of Grace 1906. New York: Haskell House, 1970.

Nwauwa, A.0. "Education, Western Africa." Pp. 1:345-53 inEncyclopedia of Western Colonialism since 1450. 2 Vols.Ed. Thomas Benjamin. Detroit: Macmillan Reference USA, 2007.

Stock, J., ed. "King Leopold II of Belgium Establishes the Congo Free State." Pp. 213-17 inAfrica. Farmington Hills, MI: Gale, 2014.

Vansina, J.Kingdoms of the Savanna. Madison: University of Wisconsin Press, 1966.

Vanthemsche, G. "Lumumba, Patrice." Pp. 2:740-41 inEncyclopedia of Western Colonialism since 1450. 2 Vols.Ed. Thomas Benjamin. Detroit: Macmillan Reference USA, 2007. 
Influence of the Congo's Leaders on its Education

Yates, B. A. "Structural Problems in Education in the Congo (Leopoldville)." Comparative Education Review 7.2 (1963): 152-62.

Zeilig, Leo. Lumumba: Africa's Lost Leader. London: Haus, 2008.

Citation: Jeremy Cheng, "Influence of the Congo's Leaders on its Education". American Research Journal of History and Culture, vol 6, no. 1; pp: 1-10.

Copyright (c) 2020 Jeremy Cheng. This is an open access article distributed under the Creative Commons Attribution License, which permits unrestricted use, distribution, and reproduction in any medium, provided the original work is properly cited. 